\title{
TWIN REVERSED ARTERIAL PERFUSION SEQUENCE (ACARDIAC TWIN): A RARE CASE REPORT
}

\author{
Chidambaram Ramesh Babu1, Madurai Padmanabhan Kanchana²
}

${ }^{1}$ Post Graduate, Department of Pathology, Institute of Pathology, Madras Medical College, Chennai.

2 Professor, Department of Pathology, Institute of Obstetrics \& Gynaecology, Chennai.

\section{ABSTRACT}

Acardiac twin is a rare congenital anomaly and is exclusively associated with monochorionic twin pregnancy. It is due to abnormal placental vascular communication between the two fetuses in the form of arterioarterial and venovenous communication (reversed perfusion). Acardiac twin receives blood from the pump twin. Twin Reversed Arterial Perfusion (TRAP) is a rare complication of monochorionic twins. TRAP sequence is known as acardius or chorioangiopagus parasiticus. It occurs in $1 \%$ of monochorionic twin pregnancies and in 1 in 35,000 pregnancies. We report a rare case of acardiac twin, the incidence among 1 in 80229 of total deliveries and 1 in 1922 of twin pregnancies (From January 2010 to September 2015) in our institution. Hence, we present this rare interesting case of acardiac twin (TRAP SEQUENCE) diagnosed and delivered at our institution.

\section{KEYWORDS}

Acardiac twin, TRAP Sequence.

HOW TO CITE THIS ARTICLE: Babu CR, Kanchana MP. "Twin reversed arterial perfusion sequence (Acardiac Twin): A rare case report." Journal of Evolution of Medical and Dental Sciences 2015; Vol. 4, Issue 103, December 24; Page: 16907-16908,

DOI: $10.14260 /$ jemds/2015/2544

\section{INTRODUCTION}

Acardiac twin or TRAP sequence is a rare complication of monochorionic twin pregnancies. ${ }^{1}$ Multiple pregnancy accounts for $1.5 \%$ of all pregnancies, acardiac twin incidence is 1 per 35,000 birth among $1 \%$ of monozygotic twins. It results from abnormal placental vascular anastomosis, blood from the normal pump twin reaches the perfused twin through arterioarterial anastomosis, flows through acardiac twin in reverse course, then returns to pump twin through venovenous anastomosis (TRAP). There is a high risk of cardiac failure and death of normal twin. Etiology is also due to primary defect in cardiac embryogenesis.

\section{CASE REPORT}

A 23-year-old female gravida. ${ }^{2}$ abortion. ${ }^{1}$ booked case in a primary health centre was diagnosed to have acardiac twin at 16 weeks of gestation. A series of USG was done (Tabulated below). She came to our institution for antenatal check up at 25 weeks of gestation. Radiofrequency ablation was done at 28 weeks of gestation as the serial ultrasound showed there was an increased volume of the perfused twin. Following ultrasound showed there was a decrease in the volume of the acardiac twin. Patient admitted with bleeding per vagina at 34 weeks in our institution. Emergency LSCS was performed. First the surviving fetus was delivered in cephalic presentation, male baby weighing 1.760 grams, APGAR-7/10 followed by extraction of the acardiac twin weighing 300 grams. The acardiac twin had a malformed head, both upper and lower limbs were present. The male baby was shifted to neonatal care unit for close monitoring. Mother and the baby was transferred to the ward and discharged in satisfactory condition.

Financial or Other, Competing Interest: None.

Submission 21-11-2015, Peer Review 23-11-2015,

Acceptance 18-12-2015, Published 24-12-2015.

Corresponding Author:

Dr. Chidambaram Ramesh Babu,

53/23, $1^{\text {st }}$ Floor,

Patchaiappan Street, Mount Road,

Chennai-2.

E-mail: drraja81@yahoo.com

DOI:10.14260/jemds/2015/2544

\begin{tabular}{|c|c|c|c|}
\hline $\begin{array}{l}\text { Date of } \\
\text { USG done }\end{array}$ & & Fetus A & Fetus B \\
\hline $4 / 5 / 15$ & MCDA & Viable, GA- $13 W+3 D$ & $\begin{array}{c}\text { Demised fetus, } \\
\text { GA-9W }\end{array}$ \\
\hline $27 / 5 / 15$ & MCDA & $\begin{array}{l}\text { GA-16W+5D,14.2gms, } \\
\text { single umbilical artery, } \\
\text { common placenta, normal } \\
\text { liquor, normal-doppler }\end{array}$ & $\begin{array}{c}\text { Acardiac } \\
\text { twin/TRAP- } \\
\text { Volume of 28cc }\end{array}$ \\
\hline $9 / 6 / 15$ & MCDA & $\begin{array}{c}\text { GA-18 Weeks+4 Days, } \\
19.4 \mathrm{gms} \\
\end{array}$ & Volume- $44 \mathrm{cc}$ \\
\hline $22 / 6 / 15$ & MCDA & $\begin{array}{c}\text { GA-20 Weeks+3 Days, } \\
28.9 \mathrm{gms} \\
\end{array}$ & Volume-49cc \\
\hline $13 / 7 / 15$ & MCDA & $\begin{array}{c}\text { GA-23 Weeks+3 Days, } \\
44.3 \mathrm{gms} \\
\end{array}$ & Volume- $170 \mathrm{cc}$ \\
\hline $27 / 7 / 15$ & MCDA & $\begin{array}{c}\text { GA-25 Weeks+3 Days, } \\
\text { 66.5gms }\end{array}$ & Volume- $370 \mathrm{cc}$ \\
\hline $24 / 8 / 15$ & RFA & GA-28 Weeks & \\
\hline $9 / 9 / 15$ & & $\begin{array}{c}\text { GA-31 Weeks+5 Days, } \\
\text { 138.2gms, cephalic } \\
\text { presentation }\end{array}$ & Volume-103cc \\
\hline $24 / 9 / 15$ & & $\begin{array}{l}\text { GA-33 Weeks+6 Days, } \\
\text { 175.6gms, hydramnios }\end{array}$ & Volume-129cc \\
\hline
\end{tabular}

MCDA-Monochorionic diamniotic twin, RFA- Radiofrequency ablation.

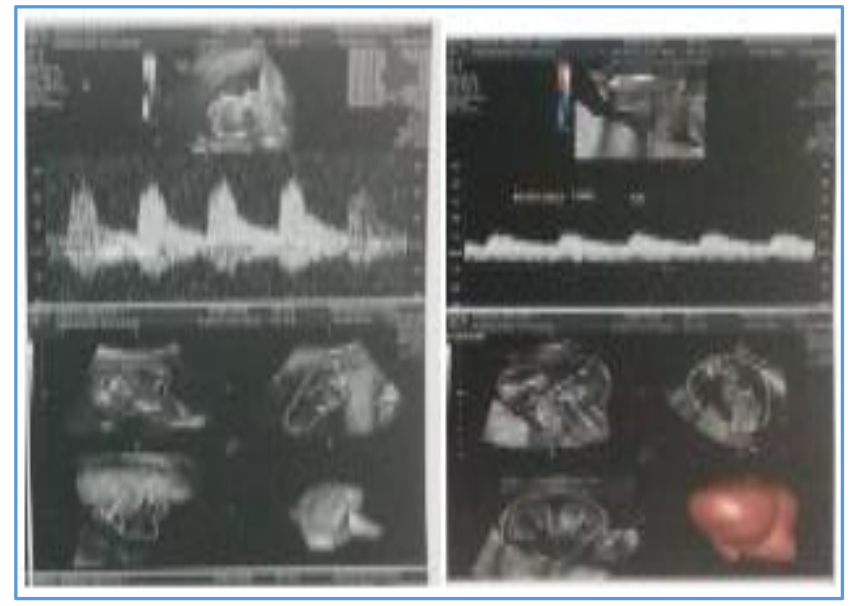

Acardiac twin before Ablation 


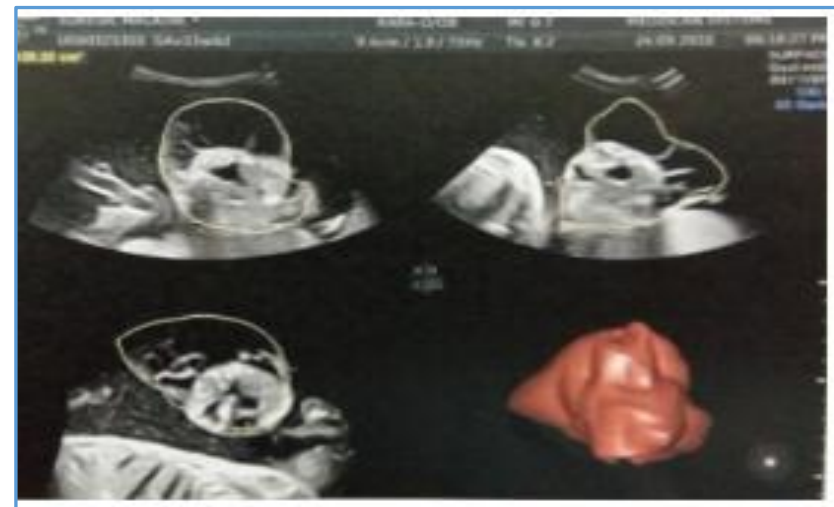

After Ablation

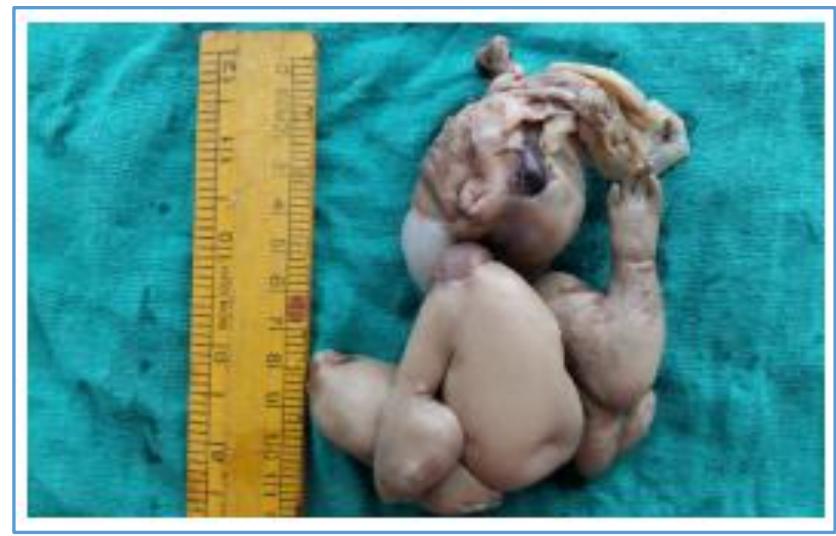

Acardiac Twin

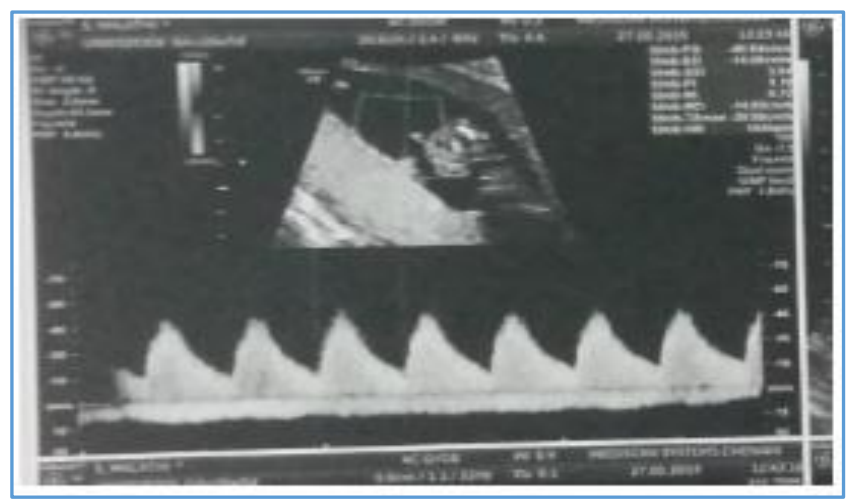

Doppler-normal Fetus

\section{DISCUSSION}

Acardiac twin is a rare congenital asymmetric duplication anomaly. It occurs in $1 \%$ of monochorionic twin or 1 in 35,000 pregnancies. ${ }^{2}$ It results from abnormal placental vascular anastomosis.
Blood from the normal pump twin reaches the perfused twin through arterio-arterial anastomosis flows through acardiac twin in reverse course, then returns to pump twin through veno-venous anastomosis (TRAP). Another theory states that there may be a primary defect in cardiac embryogenesis. ${ }^{3}$

Acardiac twin is classified based on degree of cephalic and truncal maldevelopment. 1. Acardiac-acephalus has no cephalic development. 2. Acardius-anceps has rudimentary cranial structures. 3. Acardius-amorphous has severe malformation and lacks all cephalic and truncal differentiation. 4. Acardius-acormus has cephalic structures, all other structures are absent. 4

Diagnosis of acardiac twin should be made as early by ultrasound and Doppler. It helps to show the reversed blood flow through the umbilical artery to the affected fetus and to assess the weight ratio of the twins. ${ }^{5}$

Moore et al. study concluded that perinatal mortality of $50 \%-55 \%$ is due to polyhydramnios leading to premature delivery secondary to congestive cardiac failure. If the weight ratio of acardiac twin to the weight ratio of donor fetus was $>70 \%$, the incidence of preterm delivery was $90 \%$, hydramnios was $40 \%$, congestive cardiac failure was $30 \%$ and if the ratio was $<70 \%$ the incidence was $75 \%, 30 \%, 10 \%$ respectively. ${ }^{6}$

\section{CONCLUSION}

Diagnosis of acardiac twin can be made in the first trimester itself by USG and Doppler. Early diagnosis of acardiac twin helps in prevention of preterm labour and diagnosing of cardiac failure in the pump twin.

\section{REFERENCES}

1. Chanthasenanont A, Pongrojpaw D. Acardiac twin J Med Assoc Thai 2005;88:1721-4.

2. Lee $\mathrm{H}$, Wagner AJ, Sy E, et al. Efficacy of radiofrequency ablation for TRAP sequence. Am J Obstet Gynecol 2007;196:459.e1-4.

3. Saritha S, Anjankar SS. Twin reversed arterial perfusion sequence. Int J Anat Res 2013;03:140-4.

4. Rohilla M, Chopra S, Suri V, Agarwal N and Vermani N (2008). Acardiac twin - Acephalus twins. A report of a cases and review of literature. The Medscape journal of medicine 2008;10(8):200.

5. Pandey Kiran, Arya Sangeeta, Katiyar Geetanjaly. Department of Obstetrics and Gynecology, GSVM Medical College, Kanpur - A rare case of acardiac acephalus twin pregnancy, J Obstet Gynecol India Vol. 60. No. 1: January/February 2010, pg 75-76.

6. Prameela RC, Ranganath P, Niveda S, et al. A rare case report of acardiac twin; A case report. Int J Sci Stud 2014;2(8):254-257. 